Novos Estudos Jurídicos

\title{
A EMPRESA DE BENEFÍCIOS EM FACE DO DIREITO EMPRESARIAL AMBIENTAL BRASILEIRO
}

\section{THE BENEFITS COMPANY IN LIGHT OF BRAZILIAN ENVIRONMENTAL BUSINESS $\angle A W$ \\ LA EMPRESA DE BENEFICIOS FRENTE AL DERECHO EMPRESARIAL AMBIENTAL BRASILEÑO}

\author{
Celso Antonio Pacheco Fiorillo ${ }^{1}$
}

Renata Marques Ferreira²

\section{E. Merrick Dodd, Jr.}

Licença CC BY:

Artigo distribuído sob

os termos Creative

Commons, permite

uso e distribuição

irrestrita em qualquer

meio desde que 0

autor credite a fonte

original.

\begin{abstract}
"business is permitted and encouraged by the law primarily because it is of service to the community rather than because it is a source of profit to its owners"
\end{abstract}

\section{(c)}

militante no âmbito do direito empresarial ambiental, é o primeiro professor Livre-Docente em Direito Ambiental do Brasil sendo também Doutor e Mestre em Direito das Relações Sociais. Professor da Escola da Magistratura Federal da 1a Região (AMAZONIA LEGAL)é Director Académico do Congresso de Derecho Ambiental Contemporáneo España/Brasil-Universidade de Salamanca(ESPANHA) e Miembro del Grupo de Estudios Procesales de la Universidad de Salamanca-Grupo de Investigación Reconocido IUDICIUM(ESPANHA). Professor convidado visitante da Escola Superior de Tecnologia do Instituto Politécnico de Tomar(PORTUGAL) realizando anualmente o Congresso Luso Brasileiro de Direitos Humanos na Sociedade da Informação. Professor e Pesquisador dos Programas de Doutorado/Mestrado em Direito Empresarial da UNINOVE (BRASIL). Líder do Grupo de Pesquisa do CNPq Tutela Jurídica das Empresas em face do Direito Ambiental ConstitucionalUNINOVE e Pesquisador dos Grupos de Pesquisa do CNPq Núcleo de Estudos, Pesquisas e Extensão em Direito da Cidade - UERJ, Sustentabilidade, Impactos, Racionalidades e Direitos - UFPB, Novos Direitos-UFSCAR e Responsabilidade e Funcionalização do Direito UNINOVE. Chanceler da Academia de Direitos Humanos.

2 Pós-Doutora pela Universidade de São Paulo (Escola Politécnica-USP) e Doutora em Direito das Relações Sociais (subárea de Direitos Difusos e Coletivos-Direito Ambiental) pela Pontifícia Universidade Católica de São Paulo. Mestre em Direito das Relações Sociais (subárea de Direitos Difusos e Coletivos-Direito Ambiental Tributário) pela Pontifícia Universidade Católica de São Paulo. Professora convidada da Escola Superior de Advocacia da Ordem dos Advogados do Brasil - Seção de São Paulo (ESA-OAB/SP). Foi Coordenadora do Grupo de Trabalho de Tutela Jurídica da Saúde Ambiental bem como de Tutela Jurídica da Governança Corporativa Sustentável da Comissão do Meio Ambiente da Ordem dos Advogados do Brasil-Seção de São Paulo (OAB/SP). Pesquisadora do grupo de pesquisas Novos Direitos da Universidade Federal de São Carlos - UFSCar. Professora convidada do Curso de Especialização em Saneamento Ambiental da Universidade Mackenzie. Professora de Direito Ambiental Tributário do curso de extensão universitária da Escola Paulista da Magistratura. Coordenadora do Curso de Direito das Faculdades Integradas Rio Branco. Professora Doutora das Faculdades Integradas Rio Branco (Fundação Rotary). 
Resumo: Saudada pela mídia italiana, com anúncios entusiásticos, como uma ferramenta que quer reescrever a economia e tendo como principal objetivo permitir a difusão no ordenamento jurídico itálico de empresas que no exercício da sua atividade económica têm também como objetivo a melhoria do ambiente natural e social em que operam, as denominadas empresas de benefícios, ainda que possam representar a primeira disposição da União Europeia para regulamentar este tipo de sociedade e tornar a Itália o país líder na divulgação de sociedades de benefício comum, não revelam, salvo melhor juízo, qualquer contribuição significativa para o direito empresarial ambiental brasileiro. Assim, embora guardando em certa medida compatibilidade com os principais vetores ambientais constitucionais que estruturam todas as empresas no Brasil, conforme demonstrado no presente trabalho, e mesmo representando um interessante avanço em proveito do desenvolvimento sustentável em face do balizamento normativo que sempre condicionou uma empresa tradicional geralmente definida para maximizar tão somente o lucro para os acionistas, as denominadas empresas de benefícios revelam objetivamente tímida contribuição normativa em face de nosso bem elaborado balizamento que condiciona todas as atividades econômicas no plano constitucional.

Palavras-chave: Empresa de benefícios; Direito empresarial ambiental brasileiro; Função social da empresa; Desenvolvimento sustentável.

Abstract: The so-called benefits companies were enthusiastically hailed by the Italian media as a tool aimed at rewriting the economy, by enabling the diffusion in the Italian legal system of companies that, in the exercise of their economic activity, also aim to improve the natural and social environments in which they operate. However, although the benefits companies may represent the first provision of the European Union to regulate this type of company, and make Italy the leader in their dissemination, common benefits companies have not, except in the best judgment, shown any significant contribution to Brazilian environmental business law. Thus, while retaining, to a certain extent, compatibility with the main constitutional environmental vectors by which all Brazilian companies are structured, as demonstrated in this work, and despite representing an interesting advance towards sustainable development in light of the normative guidelines that have always defined a traditional company as one that maximizes profit only for its shareholders, from an objective perspective, benefits companies have shown only a modest regulatory contribution, in light of our well-constructed guideline that conditions all economic activities at the constitutional level.

Keywords: Benefits company; Brazilian environmental business law; Company social function; Sustainable development.

Resumen: Aclamada por los medios italianos, con anuncios entusiásticos, como una herramienta que quiere reescribir la economía y que tiene como objetivo principal permitir la difusión en el ordenamiento jurídico itálico de empresas que en el ejercicio de su actividad económica tienen también como objetivo la mejoría del ambiente natural y social en que operan, las denominadas empresas de beneficios, aún que puedan representar la primera disposición de la Unión Europea para reglamentar este tipo de sociedad y convertir a Italia en el país líder en la divulgación de sociedades de beneficio común, no revelan, salvo senso común, cualquier contribución significativa para el derecho empresarial ambiental brasileño. Aunque guardando en cierta medida compatibilidad con los principales vectores ambientales constitucionales que estructuran todas las empresas en Brasil, conforme demostrado en el presente trabajo, y mismo representando un interesante avance a favor del desarrollo sustentable frente al marco normativo que siempre ha condicionado una empresa tradicional definida para maximizar las ganancias para los accionistas, las denominadas empresas de beneficios revelan objetivamente un modesto aporte normativo frente a nuestro marco bien elaborado que condiciona todas las actividades económicas en el plano constitucional. 
Palabras clave: Empresa de beneficios; Derecho empresarial ambiental brasileño; Función social de la empresa; Desarrollo sustentable.

\section{INTRODUÇÃO}

A lei italiana de 28 de dezembro de 2015, n. 208 (Lei 28.12.2015, n. 208, parágrafos 376384), adotando como modelo iniciativas existentes nos Estados Unidos ${ }^{3}$, introduziu no ordenamento jurídico de referido País europeu uma nova figura de empresa chamada "empresa de benefícios“"

Referida norma jurídica, ao indicar que:

Le disposizioni previste dai commi dal presente al comma 382 hanno lo scopo di promuovere la costituzione e favorire la diffusione di società, di seguito denominate "società benefit», che nell'esercizio di una attività economica, oltre allo scopo di dividerne gli utili, perseguono una o più finalità di beneficio comune e operano in modo responsabile, sostenibile e trasparente nei confronti di persone, comunità, territori e ambiente, beni ed attività culturali e sociali, enti e associazioni ed altri portatori di interesse

Torna possível no exercício de uma atividade econômica na Itália, que uma empresa, além da finalidade de repartição dos lucros, possa também perseguir um ou mais objetivos de benefício comum e atuar de forma responsável, sustentável e transparente com as pessoas, comunidades e com o meio ambiente sendo certo que, todos os tipos de empresas previstos no código civil italiano podem, a partir da edição de aludida norma jurídica, utilizar o modelo de empresa de benefícios podendo pois alterar os seus estatutos inserindo no objeto social os objetivos de benefício comum geral (atuar de forma responsável, sustentável e transparente com as partes interessadas ) e específico (perseguir um ou mais objetivos específicos de benefício comum). Trata-se por via de consequência de uma norma jurídica que tem o objetivo de permitir a difusão no ordenamento jurídico italiano de

3 O modelo é seguramente o norte-americano conforme consta no Relatório ao Projeto de Lei n 1882 apresentado ao Senado Italiano em 17 de abril de 2015 pelo senador Del Barba e outros, que foram então incorporados à lei geral de "estabilidade". Nos Estados Unidos, o primeiro estado a aprovar Corporações de Benefícios foi Maryland em 2010 e, a partir de $1^{\circ}$ de janeiro de 2016, os seguintes 31 estados já aprovaram leis que admitem Corporações de Benefícios: Arkansas, Arizona, Califórnia, Colorado, Connecticut, Distrito de Columbia, Flórida, Havaí, Idaho, Illinois, Indiana, Louisiana, Maryland, Massachusetts, Minnesota, Montana, Nebraska, Nevada, New Hampshire, Nova Jersey, Nova York, Oregon, Pensilvânia , Rhode Island, Carolina do Sul, Tennessee, Utah, Vermont, Virginia e West Virginia.

4 "Onorevoli Senatori. -- La presente legge si propone di promuovere la costituzione e favorire la diffusione nel nostro ordinamento di società a duplice finalità, ossia di società che nell'esercizio di una attività economica, oltre allo scopo di dividerne gli utili, perseguono una o più finalità di beneficio comune nei confronti di persone, comunità, territori e ambiente, beni ed attività culturali e sociali, enti e associazioni ed ogni altro portatore di interesse."' La presente proposta, pertanto, potrebbe rappresentare il primo provvedimento nell'ambito dell'Unione europea a disciplinare tale tipologia di società e fare dell'Italia il Paese capofila nella diffusione di società con scopo di beneficio comune." Legislatura $17^{\mathrm{a}}$ - Disegno di legge n. 1882-DISEGNO DI LEGGE d'iniziativa dei senatori DEL BARBA, Mauro Maria MARINO, SANTINI, COCIANCICH, ASTORRE, COLLINA, CUOMO, DI GIORGI, FABBRI, FRAVEZZI, GUERRIERI PALEOTTI, LAI, LUCHERINI, MIRABELLI, PEZZOPANE, SANGALLI, SCALIA E SPOSETTI-COMUNICATO ALLA PRESIDENZA IL 17 APRILE 2015 - Disposizioni per la diffusione di società che perseguono il duplice scopo di lucro e di beneficio comune 
empresas que, no exercício da sua atividade económica, têm também como objetivo a melhoria do ambiente natural e social em que operam pela utilização de práticas, processos de produção e bens capazes de produzir externalidades positivas conforme esclarece Cose5, e que visam destinar parte de seus recursos gerenciais e econômicos para a busca do crescimento do bem-estar das pessoas e comunidades, para a conservação e recuperação de ativos do património artístico e arqueológico presente no local onde se insere ou no território nacional, à divulgação e apoio a atividades culturais e sociais, bem como a organismos e associações com fins que visam a comunidade e o bem-estar social, ou seja, uma lei que visa promover o estabelecimento e promover a difusão no ordenamento jurídico italiano de sociedades de dupla finalidade, ou seja, sociedades que no exercício de uma atividade económica, para além da finalidade de repartição dos lucros, prossigam uma ou mais finalidades de benefício comum às pessoas, comunidades, territórios e meio ambiente, bens e atividades culturais e sociais, órgãos e associações e qualquer outro titular de interesse.

Assim, ao introduzir uma nova forma de entender os negócios visando uma tentativa de modificação dos tradicionais paradigmas estabelecidos no plano normativo italiano tradicional, ou seja, na tentativa de superar a abordagem "clássica" de fazer negócios, estruturada em modelo da procura, no longo prazo, da criação de valor para os acionistas com processo de tomada de decisão tomadas pelos conselheiros geralmente definidas para maximizar o lucro para os acionistas6, as empresas com o propósito de benefício comum criadas no ordenamento jurídico italiano procuram estabelecer um compromisso da empresa e, portanto, dos diretores, de perseguir uma finalidade adicional àquela de lucro resgatando em certa medida a advertência de Merrick Dodd7 do inicio dos anos 30 do século passado, a saber:

Instead of talking, as the early judges talked, in terms of the duty of one engaged in business activities toward the public who are his customers, it has become the practice since Munn v. Illinois 9 to talk of the public duty of one who has devoted his property to public use, the conception being that property employed in certain kinds of business is devoted to public use while property employed in other kinds of business remains strictly private. This approach to the problem has been justly criticized as attempting to draw an unreasonably clean-cut distinction between businesses which do not differ substantially, and as furnishing no intelligible criterion by which to distinguish those businesses which are private property from those which are property devoted to public use.10 The phrase does, however, have the merit of emphasizing the fact that

5 Referindo-se via de regra à produção ou consumo de bens ou serviços sobre terceiros que não estão diretamente envolvidos com a atividade, as denominadas externalidades podem ter natureza negativa, quando geram custos para os demais agentes, como por exemplo as hipóteses de poluição, ou natureza positiva, quando os demais agentes se beneficiam como é o caso da lei analisada.Vide COASE, R.H. The problem os social cost. The Journal of Law and Economics. Vol. 3, Number ct., 1960.

6 Trata-se do tradicional modelo de shareholders paradigma em que a empresa é apenas vista como uma entidade que gera benefícios econômicos (lucros) aos seus proprietários e acionistas, os denominados shareholders, também conhecidos como stockholders, constituídos tão somente pelos proprietários e acionistas, ou seja, por quem detém o capital da empresa.

7 DODD, Jr. E. Merrick For Whom Are Corporate Managers Trustees? Harvard Law Review Vol. 45, n. 8, maio de 1932. 
business is permitted and encouraged by the law primarily because it is of service to the community rather than because it is a source of profit to its owners. Accordingly, where it appears that unlimited private profit is incompatible with adequate service, the claim of those engaged therein that the business belongs to them in an unqualified sense and can be pursued in such manner as they choose need not be accepted by the legislature.

Trata-se por via de consequência de ajustar as atividades econômicas ao denominado " Stakeholder Capitalism "8, ou seja, dentro do que poderíamos denominar "um novo capitalismo" que se baseia na ideia de que as empresas devem assumir sua responsabilidade com a sociedade assim como devem procurar também mudar a forma como fazer negócios.

Destarte podem as referidas empresas de benefício perseguir um ou mais objetivos de benefício comum e atuar de forma responsável, sustentável e transparente com as pessoas, comunidades, territórios e meio ambiente, ativos e atividades culturais e sociais, entidades e associações e demais stakeholders, em face de sua conceituação original explicada por Edward Freeman9, no âmbito de uma nova ordem contemporânea em que as atividades econômicas-principalmente em decorrência dos efeitos da pandemia/CORONAVIRUS-indicam a necessidade de sofrer ajustes estruturais inclusive no âmbito jurídico-em face do desenvolvimento sustentável.

Daí ser útil verificar, no âmbito da realidade normativa brasileira, se a ideologia das empresas de benefício guarda compatibilidade com nosso direito empresarial ambiental em vigor. Para tanto será utilizado o método hermenêutico, por meio do levantamento dos trabalhos doutrinários elaborados por especialistas que atuam no âmbito da matéria investigada e análise jurídica afeita ao direito ambiental constitucional, bem como das normas infraconstitucionais pertinentes ao tema investigado.

Vejamos.

\section{AS EMPRESAS NO BRASIL EM FACE DO SISTEMA CONSTITUCIONAL EM VIGOR}

Tipo de "instituição econômica que gerada embrionariamente no bojo da Revolução Industrial10, ampliou-se desmedidamente até dominar o panorama da economia atual" como lembram Enders,

$8 \quad$ Stakeholder Capitalism: What Is Required from Corporate Leadership? Speakers: Jim Hagemann Snabe, Klaus Schwab, Ginni Rometty, Marc Benioff, Feike Sybesma, Brian T. Moynihan.

9 FREEMAN, R. Edward. Stockholders and Stakeholders: A New Perspective on Corporate Governance. California Management Review. (pre-1986); Spring 1983.

10 "Expressão surgida nos anos 1820 para designar uma ruptura nas formas tradicionais de produção. Por extensão, aplicou-se ao grande crescimento econômico resultante de inovações técnicas que alteraram radicalmente os métodos de trabalho. Embora o termo revolução evoque uma mudança rápida e profunda, a industrialização foi muitas vezes um processo lento, que coexistiu com modos de vida e de produção tradicionais. A Inglaterra, a partir dos anos 1780 , foi o primeiro país a entrar na era industrial". 
Ferreira, e Franco11, conforme lição fundamental de Bulgarelli 12 a empresa "como noção referível à atividade econômica organizada de produção e circulação de bens e serviços para o mercado, exercida profissionalmente, conforme alertam indicando fontes doutrinárias Fiorillo e Ferreira13 passou a ter, observando-se a noção antes referida, inequívoco enquadramento em nossa Lei Maior a partir de 1988.

Daí Eros Grau adverte14, citando Requião15 que "os juristas tradicionalmente se valem dos ensinamentos da teoria econômica para acolher a definição da empresa como "organismos econômicos, que se concretizam na organização dos fatores de produção e que se propões à satisfação das necessidades alheias, mais precisamente, das exigências do mercado em geral"; o conceito de empresa firma-se na ideia de que ela é o exercício da atividade produtiva".

Assim, entendida como "organização destinada à produção e/ou comercialização de bens e serviços, tendo como objetivo o lucro", na lição de Sandroni16,a empresa, no plano normativo infraconstitucional brasileiro, como lembram Fiorillo e Ferreira17 "teria sua gênese histórica observada no Decreto 737 de 1850 sendo prevista já naquela oportunidade no plano da mercancia ("Art. 19. Considera-se mercancia: § $3^{\circ}$ As emprezas de fabricas; de commissões ; de depositos ; de expedição, consignação e transporte de mercadorias; de espectaculos públicos").Definida no âmbito da lei 8212/91(Organização da Seguridade Social) como "firma individual ou sociedade que assume o risco de atividade econômica urbana ou rural, com fins lucrativos ou não, bem como os órgãos e entidades da administração pública direta, indireta e fundacional" (Art.15, I) e prevista em face de seu porte econômico na Lei Complementar 123/06(Art. $3^{\circ}$ Para os efeitos desta Lei Complementar, consideram-se microempresas ou empresas de pequeno porte, a sociedade empresária, a sociedade simples, a empresa individual de responsabilidade limitada e o empresário a que se refere o art. 966 da Lei 10.406, de 10 de janeiro de 2002 -Código Civil), devidamente registrados no Registro de Empresas Mercantis ou no Registro Civil de Pessoas Jurídicas, conforme o caso, desde que: I - no caso da microempresa, aufira, em cada ano-calendário, receita bruta igual ou inferior a $\mathrm{R} \$ 360.000,00$ ); e II - no caso de empresa de pequeno porte, aufira, em cada ano-calendário, receita bruta superior a $\mathrm{R} \$$ 360.000,00 e igual ou inferior a $\mathrm{R} \$ 4.800 .000,00$ ) a empresa, também com fundamento no Art.996 da lei 10.406/02(Código Civil), encontra seu balizamento normativo, como já aduzido na presente obra,

11 ENDERS, Armelle; FERREIRA, Marieta de Moraes; FRANCO, Renato. História em Curso Da antiguidade à Globalização. São Paulo: Editora do Brasil; Rio de Janeiro: Fundação Getulio Vargas, 2008.

12 BULGARELLI, Waldírio. A Teoria Jurídica da Empresa: análise jurídica da empresarialidade. São Paulo: Editora Revista dos Tribunais, 1985.

13 FIORILLO, Celso Antonio Pacheco; FERREIRA, Renata Marques. Direito Empresarial Ambiental Brasileiro e sua delimitação constitucional. Rio de Janeiro: Lumen Juris, 2020.

14 ADI 3273 / DF - DISTRITO FEDERAL AÇÃO DIRETA DE INCONSTITUCIONALIDADE Relator: Min. CARLOS BRITTO Relator(a) p/ Acórdão: Min. EROS GRAU Julgamento: 16/03/2005 Órgão Julgador: Tribunal Pleno Publicação DJ 02-03-2007 PP-00025 EMENT VOL-02266-01 PP-00102.

15 REQUIÃO, Rubens. Curso de Direito Comercial. 8a edição, São Paulo: Saraiva, 1977.

16 SANDRONI, Paulo. Novíssimo Dicionário de Economia. São Paulo: Best Seller, 1999.

17 FIORILLO, Celso Antonio Pacheco; FERREIRA, Renata Marques. Liberdade Econômica (lei 13.874/19) em face do direito ambiental constitucional brasileiro: o enquadramento jurídico das atividades econômicas vinculadas ao desenvolvimento sustentável. Rio de Janeiro: Lumen Juris, 2020. 
adstrito fundamentalmente a uma atividade econômica organizada para a produção ou a circulação de bens ou de serviços na ordem jurídica do capitalismo absorvida por nossa Lei Maior".

"Destarte, exatamente enquanto" atividade econômica organizada para a produção ou a circulação de bens ou de serviços na ordem jurídica do capitalismo absorvida por nossa Lei Maior", para utilizar a manifestação de Fiorillo e Ferreira18, a empresa, em nosso País, submete-se juridicamente no plano constitucional não só ao regramento normativo que estrutura as atividades a exemplo da lembrança destacada por Bulgarelli19 como, particularmente, "como noção referível à atividade econômica organizada de produção e circulação de bens e serviços para o mercado, exercida profissionalmente", à delimitação jurídica constitucional que organiza os princípios gerais da atividade econômica.

Por via de consequência, em face de nossa atual Carta Magna (Arts. $1^{\circ}$,IV e 170 e segs.), a empresa no Brasil, fundamentada nos valores sociais do trabalho e da livre iniciativa(Art. ${ }^{\circ}{ }^{\circ}$ IV) bem como fundada na valorização do trabalho humano e na livre iniciativa (Art.170 da CF), passou a ter por fim assegurar a todos existência digna (Arts. $1^{\circ}$, III e 170 da CF), conforme os ditames da justiça social, observando obediência obrigatória, dentre os princípios gerais das atividades econômica, ao princípio da defesa do meio ambiente, inclusive mediante tratamento diferenciado conforme o impacto ambiental dos produtos e serviços e de seus processos de elaboração e prestação(Art.170,VI da CF).

Além disso, a empresa no Brasil, ao ter sua estrutura necessariamente ligada aos referidos princípios fundamentais de nossa Carta Magna, também está vinculada ao que determina o Art. $3^{\circ}$ de nossa Lei Maior.

Destarte construir uma sociedade livre, justa e solidária; garantir o desenvolvimento nacional; erradicar a pobreza e a marginalização, reduzir as desigualdades sociais e regionais e promover o bem de todos, sem preconceitos de origem, raça, sexo, cor, idade e quaisquer outras formas de discriminação são também determinações constitucionais impostas à todas as atividades econômicas organizadas de produção e circulação de bens e serviços em nosso País como princípios fundamentais que devem ser obedecidos.

Cuida-se, portanto de entender e analisar juridicamente a empresa em nosso País, desde logo e preliminarmente, a partir de seu enquadramento constitucional, constatando especificamente dois fundamentos constitucionais que estabelecem seu superior contorno normativo: a dignidade da pessoa humana (Art. $1^{\circ}$, III) e os valores sociais do trabalho e da livre iniciativa (Art. $\left.1^{\circ}, \mathrm{IV}\right)$ princípios fundamentais constitucionais que se refletem em todas as normas constitucionais e evidentemente em toda a ordem econômica delimitada a partir do que estabelece o Art.170 que aliás, ao fixar os

18 FIORILLO, Celso Antonio Pacheco; FERREIRA, Renata Marques. Direito Empresarial Ambiental Brasileiro e sua delimitação constitucional. Rio de Janeiro: Lumen Juris, 2020.

19 BULGARELLI, Waldírio. A Teoria Jurídica da Empresa: análise jurídica da empresarialidade. São Paulo: Editora Revista dos Tribunais, 1985. 
denominados princípios gerais da atividade econômica, praticamente ratifica no âmbito do conteúdo do Art.170 os conteúdos dos Arts. $1^{\circ}$,III e $1^{\circ}$,IV de nossa Lei Maior. Daí a obediência por parte das empresas à defesa do meio ambiente restar claramente caracterizada não só em face dos princípios gerais da atividade econômica, mas principalmente em face dos princípios fundamentais de nossa Constituição Federal.

Por via de consequência, para que possam atuar de forma lícita em nosso País, as empresas necessariamente estão constitucionalmente obrigadas a defender o meio ambiente em face dos balizamentos constitucionais que estruturam referido direito.

Os contornos jurídicos delimitadores das atividades econômicas organizadas de produção e circulação de bens e serviços para o mercado em face do que determina o significado jurídico constitucional de meio ambiente necessitam, pois ser aclarados exatamente no sentido de bem esclarecer a delimitação constitucional em vigor visando constatar se a ideologia das empresas de benefício-que dentre seus objetivos destaca a melhoria do ambiente natural e social em que operam pela utilização de práticas, processos de produção e bens capazes de produzir externalidades positivas-guardam compatibilidade com nosso direito empresarial ambiental em vigor.

\section{A EMPRESA NO BRASIL COMO NOÇÃO REFERÍVEL À ATIVIDADE ECONÔMICA ORGANIZADA DE PRODUÇÃO E CIRCULAÇÃO DE BENS E SERVIÇOS PARA O MERCADO E AS ATIVIDADES PREVISTAS NO ÂMBITO DA ORDEM ECONÔMICA CONSTITUCIONAL: A DEFESA DO MEIO AMBIENTE COMO PRINCÍPIO GERAL DA ATIVIDADE ECONÔMICA EM FACE DA ORIENTAÇÃO DO SUPREMO TRIBUNAL FEDERAL (ADI 3540) E SEUS REFLEXOS NO SISTEMA NORMATIVO INFRACONSTITUCIONAL.}

Ao assegurar a todos o livre exercício de qualquer atividade econômica, independentemente de autorização de órgãos públicos, salvo nos casos previstos em lei, (parágrafo único do art. 170 da CF) nossa Constituição Federal destacou de forma importante a necessidade de se interpretar no plano superior normativo o significado de referido conceito de atividade em face de seus evidentes reflexos em toda a ordem econômica constitucional particularmente em decorrência do direcionamento estabelecido pelos próprios princípios gerais da atividade econômica (TÍTULO VII - Da Ordem Econômica e Financeira - CAPÍTULO I - DOS PRINCÍPIOS GERAIS DA ATIVIDADE ECONÔMICA).

Destarte, não se trata de pura e simplesmente compreender a atividade em face tão somente da economia, a saber, dentro do termo economia, como o "quadro físico e institucional dentro do qual se realizam as atividades de produção de bens e serviços requeridos pela sociedade, bem como sua evolução no tempo" conforme lição de Leite ${ }^{20}$, mas de compreender de que forma as

20 LEITE, Antonio Dias. A Economia Brasileira: de onde viemos e onde estamos. $2^{\mathrm{a}}$ edição, Rio de Janeiro: Elsevier, 2011. 
atividades de produção de bens e serviços requeridos pela sociedade tem seu balizamento fixado pela Constituição Federal. Trata-se, pois de verificar o que significa atividade no contexto econômico normativo constitucional lembrando, de forma evidentemente menos ampla, dentro de análise doutrinária jurídica e em contexto infraconstitucional, ser a atividade "conceito básico de direito comercial, fenômeno essencialmente humano ${ }^{21}$. E hoje se pode afirmar que é conceito básico de direito empresarial. A empresa se realiza pela atividade, como o sujeito se realiza por seus atos. Tanto $o$ ato quanto a atividade se exteriorizam por meio de negócios jurídicos, de tal sorte que se afirma que o contrato é o núcleo básico da atividade empresarial22 "como destacado por Nery²3.

Assim, atribuindo posição juridicamente superior, a Constituição Federal passou a entender a partir de 1988 ser a atividade no plano normativo econômico descrito na Lei Maior, como adverte Fiorillo e Ferreira ${ }^{24}$, "conceito bem mais amplo abarcando não só as comerciais e empresariais mas também e particularmente indicando a atividade em face da defesa do meio ambiente o que significa compreender a matéria ora desenvolvida ,como já aduzimos em outras ocasiões, em face do conceito amplo e abrangente das noções jurídicas de índole constitucional de meio ambiente natural, de meio ambiente cultural, de meio ambiente artificial (espaço urbano) e de meio ambiente laboral."

Com efeito.

Entendida, na lição de Houaiss ${ }^{25}$ como "qualidade; faculdade ou possibilidade de agir, de se mover, de fazer, empreender coisas; exercício dessa faculdade, ação" em face do que se admite ser ativo ("que exerce ação, que age, que tem a faculdade de agir"), o termo atividade também pode ser perfeitamente explicado no âmbito da economia(atividade econômica) como a faculdade de empreender coisas o que facilita evidentemente seu entendimento no contexto da ordem econômica constitucional com evidentes reflexos no direito ambiental constitucional, ou seja, a livre iniciativa passa a atuar em absoluta sintonia com os princípios fundamentais do direito ambiental constitucional ${ }^{26}$.

21 BONFANTE, Pietro Lezioni di. Storia del commercio: Era moderna. Oceânica: A. Giuffrè, 1982.

22 BULGARELLI, Waldirio. Contratos Mercantis. São Paulo: Atlas,1991.

23 NERY, Rosa. Vínculo obrigacional: relação jurídica de razão (Técnica e ciência de proporção), tese de livredocência, Pontifícia Universidade Católica de São Paulo, 2004.

24 FIORILLO, Celso Antonio Pacheco; FERREIRA, Renata Marques. Liberdade Econômica (lei 13.874/19) em face do direito ambiental constitucional brasileiro: o enquadramento jurídico das atividades econômicas vinculadas ao desenvolvimento sustentável. Rio de Janeiro: Lumen Juris, 2020.

25 HOUAISS, Antonio; VILLAR, Mauro de Salles. Dicionário Houaiss da Língua Portuguesa. Rio de Janeiro: Objetiva, 2009.

26 "A QUESTÃO DO DIREITO AO MEIO AMBIENTE ECOLOGICAMENTE EQUILIBRADO - DIREITO DE TERCEIRA GERAÇÃO - PRINCÍPIO DA SOLIDARIEDADE. - O DIREITO A INTEGRIDADE DO MEIO AMBIENTE - TIPICO DIREITO DE TERCEIRA GERAÇÃO - CONSTITUI PRERROGATIVA JURÍDICA DE TITULARIDADE COLETIVA, REFLETINDO, DENTRO DO PROCESSO DE AFIRMAÇÃO DOS DIREITOS HUMANOS, A EXPRESSAO SIGNIFICATIVA DE UM PODER ATRIBUIDO, NÃO AO INDIVIDUO IDENTIFICADO EM SUA SINGULARIDADE, MAS, NUM SENTIDO VERDADEIRAMENTE MAIS ABRANGENTE, A PROPRIA COLETIVIDADE SOCIAL. ENQUANTO OS DIREITOS DE PRIMEIRA GERAÇÃO (DIREITOS CIVIS E POLITICOS) - QUE COMPREENDEM AS LIBERDADES CLASSICAS, NEGATIVAS OU FORMAIS - REALCAM O PRINCÍPIO DA LIBERDADE E OS DIREITOS DE SEGUNDA GERAÇÃO (DIREITOS ECONOMICOS, SOCIAIS E CULTURAIS) - QUE SE IDENTIFICA COM AS LIBERDADES POSITIVAS, REAIS OU CONCRETAS - ACENTUAM O PRINCÍPIO DA IGUALDADE, OS DIREITOS DE TERCEIRA GERAÇÃO, QUE MATERIALIZAM PODERES DE TITULARIDADE COLETIVA ATRIBUIDOS GENERICAMENTE A TODAS AS FORMAÇÕES SOCIAIS, CONSAGRAM O PRINCÍPIO DA 
Assim, conforme inclusive já definido pelo Supremo Tribunal Federal se "é certo que a ordem econômica na Constituição de 1988 define opção por um sistema no qual joga um papel primordial a livre iniciativa. Essa circunstância não legitima, no entanto, a assertiva de que o Estado só intervirá na economia em situações excepcionais. Mais do que simples instrumento de governo, a nossa Constituição enuncia diretrizes, programas e fins a serem realizados pelo Estado e pela sociedade. Postula um plano de ação global normativo para o Estado e para a sociedade, informado pelos preceitos veiculados pelos seus arts. $1^{\circ}, 3^{\circ}$ e 170. A livre iniciativa é expressão de liberdade titulada não apenas pela empresa, mas também pelo trabalho. Por isso a Constituição, ao contemplá-la, cogita também da "iniciativa do Estado"; não a privilegia, portanto, como bem pertinente apenas à empresa. Se de um lado a Constituição assegura a livre iniciativa, de outro determina ao Estado a adoção de todas as providências tendentes a garantir o efetivo exercício do direito à educação, à cultura e ao desporto (arts. 23, V; 205; 208; 215; e 217, § 30, da Constituição). Na composição entre esses princípios e regras, há de ser preservado o interesse da coletividade, interesse público primário(grifos nossos). O direito ao acesso à cultura, ao esporte e ao lazer são meios de complementar a formação dos estudantes ${ }^{27}$. Por via de consequência, no plano superior constitucional em vigor (princípio fundamental), a livre iniciativa (Art.1 ${ }^{\circ}$, IV da CF) como "princípio do liberalismo econômico que defende a total liberdade do indivíduo para escolher e orientar sua ação econômica, independentemente da ação de grupos sociais ou do Estado" implicando em "total garantia da propriedade privada, o direito de o empresário investir seu capital no ramo que considerar mais favorável e fabricar e distribuir os bens produzidos em sua empresa da forma que achar mais conveniente à realização dos lucros"; conforme explicação de Sandroni ${ }^{28}$,deixa de ser observada em face de sua interpretação inicial e passa a ser admitida em contexto de evidente equilíbrio.

Trata-se a rigor, como observado por Ferreira e Fiorillo ${ }^{29}$, de se verificar que a ordem econômica estabelecida no plano normativo constitucional, fundada na valorização do trabalho humano e na livre iniciativa, tem por fim assegurar a todos existência digna, conforme os ditames da justiça social, observados alguns princípios indicados nos incisos do Art.170 sendo certo que dentre os referidos princípios, está exatamente o da defesa do meio ambiente (Art.170, VI da CF), cujo conteúdo constitucional está descrito no Art.225 da CF, inclusive mediante tratamento diferenciado conforme o impacto ambiental (Art.225, parágrafo $1^{\circ}, \mathrm{IV}$ ) dos produtos e serviços e de seus processos de elaboração e prestação.

SOLIDARIEDADE E CONSTITUEM UM MOMENTO IMPORTANTE NO PROCESSO DE DESENVOLVIMENTO, EXPANSAO E RECONHECIMENTO DOS DIREITOS HUMANOS, CARACTERIZADOS, ENQUANTO VALORES FUNDAMENTAIS INDISPONIVEIS, PELA NOTA DE UMA ESSENCIAL INEXAURIBILIDADE". MS 22164 / SP . SÃO PAULO MANDADO DE SEGURANÇA Relator :Min. CELSO DE MELLO Julgamento: 30/10/1995 Órgão Julgador: Tribunal Pleno Publicação DJ 17-11-1995 PP-39206 EMENT VOL-01809-05 PP-01155

27 ADI 1.950, rel. min. Eros Grau, j. 3-11-2005, P, DJ de 2-6-2006.

28 SANDRONI, Paulo. Novíssimo Dicionário de Economia. São Paulo: Best Seller, 1999.

29 FIORILLO, Celso Antonio Pacheco; FERREIRA, Renata Marques. Direito Empresarial Ambiental Brasileiro e sua delimitação constitucional. Rio de Janeiro: Lumen Juris, 2020. 
Destarte, a defesa do meio ambiente embora adote como causa primária no plano normativo os valores sociais do trabalho e da livre iniciativa (Art. $1^{\circ}, \mathrm{IV}$ ) necessita respeitar a dignidade da pessoa humana como superior fundamento constitucional (Art. $1^{\circ}$, III) levando o Supremo Tribunal Federal a fixar a adequada interpretação da matéria, com base em interpretação que já vinha sendo desenvolvida pela doutrina a partir do ano 2000 como lembra Fiorillo ${ }^{30}$, conforme decidiu na conhecida ADI 3540 cuja ementa, por sua evidente importância para o tema analisado na presente obra ,merece ser transcrito, a saber:

A atividade econômica não pode ser exercida em desarmonia com os princípios destinados a tornar efetiva a proteção ao meio ambiente. A incolumidade do meio ambiente não pode ser comprometida por interesses empresariais nem ficar dependente de motivações de índole meramente econômica, ainda mais se se tiver presente que a atividade econômica, considerada a disciplina constitucional que a rege, está subordinada, entre outros princípios gerais, àquele que privilegia a "defesa do meio ambiente" (CF, art. 170, VI), que traduz conceito amplo e abrangente das noções de meio ambiente natural, de meio ambiente cultural, de meio ambiente artificial (espaço urbano) e de meio ambiente laboral. Doutrina. Os instrumentos jurídicos de caráter legal e de natureza constitucional objetivam viabilizar a tutela efetiva do meio ambiente, para que não se alterem as propriedades e os atributos que lhe são inerentes, o que provocaria inaceitável comprometimento da saúde, segurança, cultura, trabalho e bem-estar da população, além de causar graves danos ecológicos ao patrimônio ambiental, considerado este em seu aspecto físico ou natural. [ADI 3.540 MC, rel. min. Celso de Mello, j. 1-9-2005, P, DJ de 3-2-2006.]".

Assim ao assegurar a todos o livre exercício de qualquer atividade econômica, nossa Constituição Federal condiciona o exercício de referida atividade no plano normativo superior, incluindo-se evidentemente as atividades econômicas organizadas de produção e circulação de bens e serviços para o mercado (EMPRESAS) à defesa do meio ambiente natural, do meio ambiente cultural, do meio ambiente artificial (espaço urbano) e do meio ambiente laboral tudo em face dos princípios do direito ambiental constitucional na forma de suas respectivas tutelas jurídicas constitucionais. Daí, particularmente, ser princípio fundamental interpretativo de todo o nosso sistema constitucional, os valores sociais da livre iniciativa (Art. $1^{\circ}$, IV da CF).

\section{EMPRESA NO BRASIL E SUA FUNÇÃO SOCIAL}

Relembrando a advertência de Dodd ${ }^{31}$, a saber " business is permitted and encouraged by the law primarily because it is of service to the community rather than because it is a source of profit to its owners", devemos destacar que como atividade econômica organizada de produção e circulação de

30 FIORILLO, Celso Antonio Pacheco. in Curso de Direito Ambiental Brasileiro. São Paulo: Editora Saraiva, 2000.

31 DODD, Jr. E. Merrick For Whom Are Corporate Managers Trustees? Harvard Law Review Vol. 45, no. 8, maio de 1932. 
bens e serviços para o mercado, a empresa, em decorrência do que estabelece nosso sistema normativo constitucional ,também está balizada normativamente em face de sua função social como adverte Eros Grau 32 . Trata-se de captar, na lição de Bulgareli33 "a sua função através do papel que exerce no ambiente socioeconômico, como agente de produção e circulação de bens ou serviços para o mercado, numa economia de massa, tendo sido identificados em consequência, os interesses que nela convergem, e do choque (rectius: conflito) entre eles" chegando "à valoração dos que deveriam ser tutelados".

Daí a advertência do referido autor ao indicar que "foi considerando a empresa como tendo a função de produzir ou fazer circular bens e serviços numa economia de massa em que impera o consumismo, que se deu relevo à empresa, como atividade funcional, o que desloca o seu titular do âmbito estrito dos direitos subjetivos, para encaminha-lo para o direito-função ou poderdever, fazendo-se presente sua responsabilidade para com os que se relacionam com a empresa (trabalhadores, credores, consumidores, o Estado, a comunidade, etc.) no que se tenteou de certa forma, dar conteúdo às formulações mais genéricas de função social (bem público, interesse geral, etc.)" recordando-se inclusive lição de Fabio Comparato ${ }^{34}$ que reconhecendo a existência de empresas que exercem autêntica função social, explicita ser "função em direito é um poder de agir sobre a esfera jurídica alheia no interesse de outrem, jamais em proveito do próprio titular".

\section{Com efeito.}

Historicamente o denominado novo direito social e econômico, que teria quebrado o predomínio do direito privado a partir da primeira Guerra Mundial "e que haveria de dissolver a sua unidade interna", como ensinava Franz Wieacker ${ }^{35}$, "tinha sido preparado pelo facto de se ter mantido nos direitos particulares alemães do séc. XIX uma massa jurídica não liberal, proveniente concretamente, das estruturas políticas feudais, do estado autoritário (ou estado-providencia), massa que era constituída pelo conjunto do direito público respeitante ao solo, do direito das águas, da caça e da pesca e do direito agrário relativo à terra, ao crédito e às sucessões" sendo certo que "fora apenas no domínio da economia industrial e comercial que o ideal liberal da livre empresa se impusera na Regulamentação empresarial do Império de 1869 \{Reichsgewerbeordnung\},a primeira das leis do Império unificado".

Advertia o experiente professor e advogado alemão que em quase todos os domínios antes referidos "as antigas tradições da administração territorial ingressaram diretamente, muitas vezes sem corte visível, no movimento que se desenvolvia neste século no sentido do direito social" destacando

32 GRAU, Eros Roberto. Comentários ao artigo 170. in Comentários à Constituição do Brasil. São Paulo: Saraiva/ Almedina, 2013.

33 BULGARELLI, Waldírio. A Teoria Jurídica da Empresa: análise jurídica da empresarialidade. São Paulo: Editora Revista dos Tribunais, 1985.

34 COMPARATO, Fábio Konder. A reforma da empresa. RDM, n. 50, 1983.

35 WIEACKER, Franz. História do Direito Privado Moderno Lisboa: Fundação Calouste Gulbenkian, 1993. 
que "o lugar central coube aqui às associações económicas e profissionais de empresários e dos trabalhadores e à sua influencia sobre o mercado, associações que o Estado autoritário e o liberalismo clássico (em contradição com a proclamação da liberdade de reunião e associação) tinham impedido durante largo tempo".

O inicio de referida evolução, na interpretação do autor antes citado, "foi constituído pela economia de guerra da $1^{a}$ Grande Guerra (grifos nossos), que trouxe pela primeira vez consigo graves restrições à liberdade contratual e à liberdade de utilização da propriedade, ao publicizar a comercialização de quase todos os bens e ao tomar medidas legislativas relativas à carência de habitação. Ao mesmo tempo, e depois de longa desconfiança, ela atribuiu pela primeira vez às grandes associações formadas durante a revolução industrial como poderes espontâneos, v.g., os cartéis de empresários e as uniões patronais, funções de integração económico-política. Depois da guerra, mantiveram-se durante muito tempo as restrições no mercado de habitação e no comércio fundiário; no mercado do carvão e da potassa um vasto domínio da produção de matérias primas foi subtraído à economia privada liberal, como concessão às tendências socializantes da economia de guerra e da primeira fase revolucionária, e submetido à uma administração autónoma orientada por uma política econômica global".

Demonstrando de forma didática que "as tendências da evolução do direito privado têm também frequentemente que ser compreendidas à luz destas mutações da constituição econômica alemã (e, em grande parte, também europeia e norte americana"), explicitava que "esta constituição força, em todo o lado onde a livre concorrência falha e a solidariedade social é ameaçada, à intervenção dos poderes públicos e à assunção de uma função dirigente pela administração pública da economia".

A expressão jurídica de referida necessidade teria então sido constituída, conforme ensinamentos de Franz Wieacker ${ }^{36, "}$ pelas novas formas jurídicas que então se formaram um pouco por toda a parte no direito público da terra, no direito da habitação e da construção civil, no direito do arrendamento, no direito do trabalho e no direito da economia e que haveria de ser sintetizada, na fórmula antecipadora de Otto von Gierke, como direito social. O princípio funcional comum a este novo domínio charneira entre o direito público tradicional e o direito privado, nos quais a confrontação entre Estado e sociedade tinham encontrado a sua expressão clássica, é o de que o decurso das funções sociais e económicas não é dirigido nem pela ordenação estadual directa nem pelo livre jogo da autonomia privada dos sujeitos económicos, mas pela cooperação entre os grupos sociais ou por uma concorrência coordenada pelos poderes públicos" concluindo que" uma vez que o que o que aqui se exprimia era a irresistível integração da sociedade económica na ordem jurídica pública(integração que o jusracionalismo liberal e o liberalismo clássico não tinham pretendido), estes princípios foram-se impondo constantemente na realidade jurídica alemã do século XX através de todas as mudanças dos governos e sistemas políticos. Hoje, eles impregnam tão profundamente a consciência social que se transformam porventura no único fundamento comum à consciência

36 WIEACKER, Franz. História do Direito Privado Moderno Lisboa: Fundação Calouste Gulbenkian, 1993. 
jurídica alemã da actualidade". Daí inclusive a lição de Konrad Hesse ${ }^{37}$, ao explicar a propriedade exatamente "sob as garantias jurídico - fundamentais, que são essenciais para a ordem econômica e social" ajustada " a um sistema amplo de medidas de planificação, guia e coordenação, em medida crescente, também, de proteção ao meio ambiente".

Destarte notamos que o denominado princípio da função social, vinculado que está historicamente ao direito social desenvolvido pela doutrina alemã, tem sua gênese claramente associada à ordem econômica e particularmente "às associações económicas e profissionais de empresários e dos trabalhadores e à sua influencia sobre o mercado" conforme ensinamentos de Franz Wieacker ${ }^{38}$. Devendo ser interpretado como tendência de evolução do direito privado bem como compreendido "à luz destas mutações da constituição econômica alemã (e, em grande parte, também europeia e norte americana)", o referido princípio teria influenciado a doutrina brasileira particularmente em face da recepção do Direito Civil alemão que" deu-se intensamente nas codificações de 1916 e 2002" como adverte Otavio Rodrigues Junior ${ }^{39}$.

Ao recordar que o substantivo functio, na língua matriz seria "derivado do verbo depoente fungor(functus sum, fungi) "cujo significado primigênio é de cumprir algo, ou desempenhar-se de um dever ou uma tarefa", observa Fabio Comparato ${ }^{40}$ que na "análise institucional do direito, que corresponde de certa forma ao funcionalismo sociológico de E. Durkheim, Bronislaw Malinovski e A.R.Radcliffe-Brown, usa-se do termo função para designar a finalidade legal de um instituto jurídico, ou seja, o bem ou o valor em razão do qual existe, segundo a lei, esse conjunto estruturado de normas" podendo também a função jurídica" ser tomada, num sentido mais abstrato, como atividade dirigida a um fim e comportando, de parte do sujeito agente, um poder ou competência" .Ao aduzir referido autor que "se analisarmos mais de perto esse conceito abstrato de função, em suas múltiplas espécies, veremos que o escopo perseguido pelo agente é sempre o interesse alheio, e não o próprio do titular do poder" conclui que "há funções exercidas no interesse de uma pessoa ou de pessoas determinadas-como o pátrio poder, a tutela e a curatela- e funções que devem ser desempenhadas em benefício da coletividade. Na ultima hipótese, e somente nela, parece-me mais apropriado falar em função social".

Observada no plano estrutural constitucional como princípio fundamental vinculado ao trabalho e à livre iniciativa (Art. $1^{\circ}$, IV da CF) tendo como escopo a dignidade da pessoa humana (Art. $1^{\circ}$, III da CF) e com reflexos diretos no âmbito dos direitos e garantias fundamentais não só no plano dos direitos individuais como principalmente coletivos (Art.5 $5^{\circ}, \mathrm{XXIII}$ ), exatamente no sentido de ser desempenhada em benefício da coletividade, a função social deve ser compreendida no âmbito

37 HESSE, Konrad. Elementos de Direito Constitucional da República Federal da Alemanha. Porto Alegre: Sergio Antonio Fabris Editor, 1998.

38 WIEACKER, Franz. História do Direito Privado Moderno Lisboa: Fundação Calouste Gulbenkian, 1993.

39 RODRIGUES JUNIOR, Otavio Luiz. A influência do BGB e da doutrina alemã no direito civil brasileiro do século XX. São Paulo: Revista dos Tribunais, 2013.

40 COMPARATO, Fábio Konder. Estado, Empresa e Função Social. São Paulo: Revista dos Tribunais, vol. 732, 1996. 
de nossa Carta Magna, a exemplo de sua gênese histórica, em face de toda nossa Ordem Econômica e Financeira, a saber, não só em decorrência de sua existência diretamente constatada no Art.170,III da Lei Maior, vinculada diretamente à propriedade mas no plano geral dos princípios da atividade econômica(Art.170,I a IX). Daí, dentro de sua finalidade legal constitucional, estar à função social associada não só de forma direta ao instituto jurídico da propriedade (Art.5 , XXIII, Art.170, III, Art.182, parágrafo $2^{\circ}$, Art.186) "como instrumento normativo fundamental destinado a organizar desde o século XIX a ordem econômica que sempre imperou em nosso País e se estabeleceu no plano jurídico através de nossas Constituições (de 1824, 1891, 1934, 1937, 1946, 1967, 1969 e 1988)" mas também de forma infinitamente mais ampla e via de regra vinculada à ordem econômica, como salientam Fiorillo e Ferreira ${ }^{41}$ "no plano da política urbana quando então está vinculada às cidades do Brasil(Art.182,caput) e aos imóveis rurais(Arts.183 a 191) ficando, pois bem caracterizado em nosso sistema constitucional que a função social, ligada que está preponderantemente à ordem econômica, deve ter seus reflexos necessariamente reconhecidos em todo o nosso plano normativo constitucional e infra constitucional visando exatamente estabelecer balizas jurídicas para as atividades econômicas desempenhadas em benefício da coletividade."

\section{EMPRESA NO BRASIL E DESENVOLVIMENTO SUSTENTÁVEL}

Impregnado de caráter eminentemente constitucional e reverberando nos Princípios Gerais da Atividade Econômica estabelecidos em nossa Lei Maior (Art.170 e segs. da CF) "como fator de obtenção do justo equilíbrio entre as exigências da economia e as da ecologia" 42., o princípio do desenvolvimento sustentável surgiu, inicialmente, de forma mais geral na Conferência Mundial de Meio Ambiente, realizada, em $1972^{43}$ em Estocolmo e repetida nas demais conferências sobre o meio ambiente. Dai ser relevante registrar na lição de Cabriilo ${ }^{44}$ que "La expresión «desarrollo sostenible» ha cobrado una gran relevancia en la literatura económica en los últimos años. Y, como tantas veces sucede con términos que en algún momento se ponen de moda, no resulta fácil saber cuál es su

41 FIORILLO, Celso Antonio Pacheco; FERREIRA, Renata Marques. Direito Empresarial Ambiental Brasileiro e sua delimitação constitucional. Rio de Janeiro: Lumen Juris, 2020.

42 A questão do desenvolvimento nacional $\left(C F\right.$, art. $\left.3^{\circ}, \mathrm{II}\right)$ e a necessidade de preservação da integridade do meio ambiente (CF, art. 225): O princípio do desenvolvimento sustentável como fator de obtenção do justo equilíbrio entre as exigências da economia e as da ecologia. O princípio do desenvolvimento sustentável, além de impregnado de caráter eminentemente constitucional, encontra suporte legitimador em compromissos internacionais assumidos pelo Estado brasileiro e representa fator de obtenção do justo equilíbrio entre as exigências da economia e as da ecologia, subordinada, no entanto, a invocação desse postulado, quando ocorrente situação de conflito entre valores constitucionais relevantes, a uma condição inafastável, cuja observância não comprometa nem esvazie o conteúdo essencial de um dos mais significativos direitos fundamentais: o direito à preservação do meio ambiente, que traduz bem de uso comum da generalidade das pessoas, a ser resguardado em favor das presentes e futuras gerações." ADI 3.540 MC, rel. min. Celso de Mello, j. 1-9-2005, P, DJ de 3-2-2006.

43 REPORT OF THE UNITED NATIONS CONFERENCE ON THE HUMAN ENVIRONMENT Stockholm, 5 a 16 June 1972.

44 CABRILLO, Francisco. La economía del desarrollo en el siglo XXI - El desafío actual consiste en extender el progreso a aquellos países y a aquellas personas que todavía hoy viven en condiciones lamentables. Nueva Revista, 2009. 
sentido preciso, si es que lo tiene. La idea de que el desarrollo de una cierta actividad debe ser «sostenible» si queremos que se mantenga a largo plazo es bastante clara. No se puede, por ejemplo, pensar que se podrá seguir explotando un determinado banco de pesca si no se sigue una estrategia racional, consistente en adaptar el volumen de capturas a su capacidad de reproducción y evitar que se capturen ejemplares muy jóvenes. Pero cosa muy diferente es tratar de aplicar estas ideas al conjunto de la actividad económica.Lo que los teóricos del desarrollo sostenible afirman no es, en efecto, que el crecimiento de un sector se verá afectado en el futuro por su sobreexplotación, sino que el conjunto del desarrollo de la economía en el mundo llegará en un plazo no muy largo al estancamiento por una utilización inadecuada de los recursos naturales."

\section{Com efeito.}

Lembra Gutierrez ${ }^{45}$ que "el origen del concepto de desarrollo sostenible está asociado a la preocupación creciente existente en la comunidad internacional en las últimas décadas del siglo XX al considerar el vínculo existente entre el desarrollo económico y social y sus efectos más o menos inmediatos sobre el medio natural. Esto, como se expondrá algo más adelante, no se trataba de un conflicto nuevo. Lo nuevo fue la magnitud y extensión alcanzada por el mismo, que condujo a una valoración sobre sus consecuencias futuras, incluida dentro de ellas la capacidad de supervivencia de la especie humana".

De qualquer forma, e com destaque para o tema examinado no presente trabalho, a Comissão Mundial sobre o Meio Ambiente criada em 1983 elaboradora do Relatório Brundtland-1987(Nosso Futuro Comum - Comissão Mundial sobre o Meio Ambiente e Desenvolvimento,1991),como lembram Fiorillo e Ferreira ${ }^{46}$ ao estabelecer que o desenvolvimento sustentável, em essência "é um processo de transformação no qual a exploração de recursos, a direção dos investimentos, a orientação do desenvolvimento tecnológico e a mudança institucional se harmonizam e reforçam o potencial presente e futuro a fim de atender às necessidades e aspirações humanas", se dirigindo também à empresa privada ${ }^{47}$ (grifos nossos), deixou explicitado que "o desenvolvimento sustentável é aquele que atende às necessidades do presente sem comprometer a possibilidade de as gerações futuras atenderem a suas próprias necessidades" contendo "dois conceitos chave", a saber:

45 "La toma de conciencia a nivel mundial de la estrecha relación existente entre el desarrollo económico y el medio ambiente, tuvo su expresión en el marco de las Naciones Unidas con la creación por este organismo en el año 1983 de la Comisión de Desarrollo y Medio Ambiente, integrada por un grupo de personalidades del ámbito científico, político y social, representativo de los diversos intereses existentes en la comunidad internacional. Para dirigir esta Comisión fue designada la señora Gró Harlem Brundtland, en aquel entonces primer ministro de Noruega, quien tenía un papel destacado por sus criterios e intervenciones en los temas ambientales. En abril del año 1987 la Comisión publicó y dio a conocer su informe, titulado "Nuestro futuro común" ("Our common future", en idioma inglés) conocido también como "Informe Brundtland" (Brundtland, G.H., 1987) en el cuál se introduce el concepto de desarrollo sostenible, definido en estos términos: "Está en manos de la humanidad asegurar que el desarrollo sea sostenible, es decir, asegurar que satisfaga las necesidades del presente sin comprometer la capacidad de las futuras generaciones para satisfacer las propias". GUTIÉRREZ, Carlos Gómez. El desarrollo sostenible: conceptos básicos, alcance y criterios para su evaluación. https://en.unesco.org/, 2017.

46 FIORILLO, Celso Antonio Pacheco; FERREIRA, Renata Marques. Direito Empresarial Ambiental Brasileiro e sua delimitação constitucional. Rio de Janeiro: Lumen Juris, 2020.

47 "A Comissão de dirige também à empresa privada, desde a formada por uma só pessoa até a grande companhia multinacional.com um movimento total superior ao de muitos países, e com possibilidades de promover mudanças e melhorias de grande alcance". ONU. Nosso Futuro Comum. $2^{\mathrm{a}}$ edição, Rio de Janeiro: Editora Fundação Getúlio Vargas, 1991. 
1) o conceito de "necessidades" (sobretudo as "necessidades" essências dos pobres do mundo, que devem receber máxima prioridade") e

2) a "noção das limitações que o estágio da tecnologia e da organização social impõem ao meio ambiente, impedindo-o de atender às necessidades presentes e futuras".

Consequentemente fixou o Relatório Brundtland que "satisfazer as necessidades e aspirações humanas é o principal objetivo do desenvolvimento" sendo certo que" a satisfação das necessidades essenciais depende em parte de que se consiga o crescimento potencial pleno, e o desenvolvimento sustentável exige claramente que haja crescimento econômico em regiões onde tais necessidades não estão sendo atendidas".

Mais tarde, a Conferência das Nações Unidas sobre o Desenvolvimento Sustentável realizada no Rio de Janeiro/BRASIL em junho de 2012 - a Rio+20 -, ao publicar seu documento final intitulado O FUTURO QUE QUEREMOS reafirmou todos os princípios da Declaração do Rio sobre o Meio Ambiente e Desenvolvimento. Com efeito.

Na Constituição Federal de 1988, o princípio do desenvolvimento sustentável encontra-se gravado de forma explícita no caput do art. 225:

Todos têm direito ao meio ambiente ecologicamente equilibrado..., impondose ao Poder Público e à coletividade o dever de defendê-lo e preservá-lo para as presentes e futuras gerações"

Constata-se que os recursos ambientais não são inesgotáveis, tornando-se inadmissível que as atividades econômicas desenvolvam-se alheias a esse fato. Busca-se com isso a coexistência harmônica entre economia e meio ambiente. Permite-se o desenvolvimento, mas de forma sustentável, planejada, para que os recursos hoje existentes não se esgotem ou tornem-se inócuos.

Destarte, conforme entendimento já adotado pelo Supremo Tribunal Federal "A análise de compatibilidade entre natureza e obra humana é ínsita à ideia de desenvolvimento sustentável, expressão popularizada pelo relatório Brundtland, elaborado em 1987 pela Comissão Mundial sobre o Meio Ambiente e Desenvolvimento. A mesma organização eficiente dos recursos disponíveis que conduz ao progresso econômico, por meio da aplicação do capital acumulado no modo mais produtivo possível, é também aquela capaz de garantir o racional manejo das riquezas ambientais em face do crescimento populacional. Por conseguinte, a proteção ao meio ambiente, no contexto de um desenvolvimento sustentável, não equivale a uma visão estática dos bens naturais, que pugna pela proibição de toda e qualquer mudança ou interferência em processos ecológicos ou correlatos. A história humana e natural é feita de mudanças e adaptações, 
não de condições estáticas ou de equilíbrio"48 Dessa forma, o princípio do desenvolvimento sustentável tem por conteúdo, como adverte Fiorillo49" a manutenção das bases vitais da produção e reprodução do homem e de suas atividades, garantindo igualmente uma relação satisfatória entre os homens e destes com o seu ambiente, para que as futuras gerações também tenham oportunidade de desfrutar os mesmos recursos que temos hoje à nossa disposição".

Com isso, acrescenta Fiorillo 50 "a noção e o conceito de desenvolvimento, formados num Estado de tradicional concepção liberal fixada em momento histórico absolutamente diferente dos dias de hoje, alteraram-se, porquanto não mais encontravam guarida na sociedade moderna. Passou-se a reclamar um papel ativo do Estado no socorro dos valores ambientais, conferindo outra noção ao conceito de desenvolvimento. A proteção do meio ambiente e o fenômeno desenvolvimentista (sendo composto pela livre iniciativa) passaram a fazer parte de um objetivo comum, pressupondo "a convergência de objetivos das políticas de desenvolvimento econômico, social, cultural e de proteção ambiental"51. A busca e a conquista de um 'ponto de equilíbrio' entre o desenvolvimento social, o crescimento econômico e a utilização dos bens ambientais exigem um adequado planejamento que tenha em conta os limites da sustentabilidade. $\mathrm{O}$ critério do desenvolvimento sustentável deve valer, conforme indicado na obra de Fiorillo ${ }^{52}$ tanto para o território nacional na sua totalidade, áreas urbanas e rurais, como para a sociedade, para o povo, respeitadas as necessidades culturais e criativas do país".

Como se percebe, o princípio possui grande importância afetando diretamente o exercício de toda e qualquer atividade econômica(Art.170 e segs da CF) bem como ocasionando necessários reflexos na própria atuação do Estado como agente normativo e regulador vez que numa sociedade desregrada, à deriva de parâmetros constitucionais balizadores da livre concorrência e da livre iniciativa, o caminho inexorável para o caos ambiental é uma certeza. Não há dúvida de que o desenvolvimento econômico também é um valor precioso da sociedade. Todavia, a preservação ambiental e o desenvolvimento econômico devem coexistir, de modo que aquela não acarrete a anulação deste.

48 ADC 42 / DF - DISTRITO FEDERAL Relator(a): Min. LUIZ FUX Julgamento: 28/02/2018 Órgão Julgador: Tribunal Pleno Publicação PROCESSO ELETRÔNICO DJe-175 DIVULG 12-08-2019 PUBLIC 13-08-2019

49 FIORILLO, Celso Antonio Pacheco. in Curso de Direito Ambiental Brasileiro. $21^{a}$ edição São Paulo: Editora Saraiva, 2021.

50 FIORILLO, Celso Antonio Pacheco. in Curso de Direito Ambiental Brasileiro. 21 ${ }^{a}$ edição São Paulo: Editora Saraiva, 2021.

51 O Tribunal Regional Federal da 3를 Região (São Paulo/Mato Grosso do Sul) adotou nosso entendimento, conforme se observa de importante decisão da Presidente do TRF, Desembargadora Federal Marli Marques Ferreira, ao enfrentar o tormentoso tema da queima da palha da cana-de-açúcar, a saber: "Celso Antonio Pacheco Fiorillo, com a proficiência de profundo conhecedor da matéria e cuidando do Princípio do Desenvolvimento Sustentável, leciona: 'Com isso, a noção e o conceito de desenvolvimento, formados num Estado de concepção liberal, alteraram-se, porquanto não mais encontravam guarida na sociedade moderna. Passou-se a reclamar um papel ativo do Estado no socorro dos valores ambientais, conferindo outra noção ao conceito de desenvolvimento. A proteção do meio ambiente e o fenômeno desenvolvimentista (sendo composto pela livre iniciativa) passaram a fazer parte de um objetivo comum, pressupondo 'a convergência de objetivos das políticas de desenvolvimento econômico, social, cultural e de proteção ambiental"' (TRF, 3ª Região, Proc. n. 2007.03.00.091882-6, requerente: Estado de São Paulo, requerido: Juízo Federal da $1^{a}$ Vara de Jaú - Seç. Jud. - SP, setembro de 2007).

52 FIORILLO, Celso Antonio Pacheco. in Curso de Direito Ambiental Brasileiro. $21^{a}$ edição São Paulo: Editora Saraiva, 2021. 
Em resumo cabe ratificar a mensagem do Relatório Brundtland 1987(Nosso Futuro Comum,1991) que, ao estabelecer o conceito de desenvolvimento sustentável, deixou claro que a comunicação da ONU foi dirigida "as pessoas, cujo bem estar é o objetivo ultimo de todas as políticas referentes a meio ambiente e desenvolvimento".

Atento a esses fatos, o legislador constituinte de 1988 verificou que o crescimento das atividades econômicas merecia um novo tratamento. Não mais poderíamos permitir que elas se desenvolvessem alheias aos fatos contemporâneos. A preservação do meio ambiente passou a ser palavra de ordem, porquanto sua contínua degradação implicará diminuição da capacidade econômica do País, e não seria possível à nossa geração e principalmente às futuras desfrutar uma vida com qualidade.

Assim, a livre iniciativa, que rege as atividades econômicas, passou a ter necessariamente outro significado necessitando adequada interpretação contemporanea. A liberdade de agir e dispor tratada pelo Texto Constitucional (a livre iniciativa) passou a ser compreendida de forma mais restrita, o que significa dizer que não existe a liberdade, a livre iniciativa, voltada à disposição de um meio ambiente ecologicamente equilibrado. Busca-se, na verdade, a coexistência de ambos sem que a ordem econômica inviabilize um meio ambiente ecologicamente equilibrado e sem que este obste o desenvolvimento econômico.

Daí, a Constituição Federal estabelecer que a ordem econômica, fundada na livre iniciativa (sistema de produção capitalista) e na valorização do trabalho humano (limite ao capitalismo selvagem), deverá regrar-se pelos ditames de justiça social, respeitando o princípio da defesa do meio ambiente, contido no inciso VI do art. 170. Assim, caminham lado a lado a livre concorrência e a defesa do meio ambiente, a fim de que a ordem econômica esteja voltada à justiça social estruturada por desenvolvimento sustentável conforme o dispositivo abaixo indicado:

Art. 170. A ordem econômica, fundada na valorização do trabalho humano e na livre iniciativa, tem por fim assegurar a todos existência digna, conforme os ditames da justiça social, observados os seguintes princípios:

\section{$(\ldots)$}

$\mathrm{VI}$ - defesa do meio ambiente, inclusive mediante tratamento diferenciado conforme o impacto ambiental dos produtos e serviços e de seus processos de elaboração e prestação. 
Devemos lembrar que a ideia principal é assegurar a existência digna da pessoa humana, através de uma vida com qualidade 53 e 54 .

Com isso, ratificando o que foi aduzido anteriormente, o princípio não objetiva impedir o desenvolvimento econômico. Sabemos que a atividade econômica, na maioria das vezes, representa alguma degradação ambiental. Todavia, o que se procura é minimizá-la, pois pensar de forma contrária significaria dizer que nenhum empreendimento que venha a afetar o meio ambiente poderá ser instalado, e não é essa a concepção apreendida do texto. O correto é que as atividades sejam desenvolvidas lançando-se mão dos instrumentos existentes adequados para a menor degradação possível. Por isso, delimita-se o princípio do desenvolvimento sustentável como o desenvolvimento que atenda às necessidades do presente, sem comprometer as futuras gerações dentro dos parâmetros anteriormente indicados.

Assim, e em apertada síntese, a defesa do meio ambiente tem objetivos bem definidos no plano constitucional com particular destaque à construção de uma sociedade livre, justa e solidária $\left(\right.$ Art. $\left.3^{\circ}, I\right)$, garantir o desenvolvimento nacional(Art. $3^{\circ}$, II) e particularmente, em face da realidade brasileira, erradicar a pobreza e a marginalização e reduzir as desigualdades sociais e regionais(Art.3, III). Daí a orientação do STF advertindo que", não se deve desprezar que a mesma Constituição protetora dos recursos ambientais do país também exorta o Estado brasileiro a garantir a livre iniciativa (artigos $1^{\circ}$, IV, e 170) e o desenvolvimento nacional (art. $3^{\circ}$, II), a erradicar a pobreza e a marginalização, a reduzir as desigualdades sociais e regionais (art. $3^{\circ}$, III; art. 170, VII), a proteger a propriedade (art. $5^{\circ}$, caput e XXII; art. 170 , II), a b uscar o pleno emprego (art. 170, VIII; art. 6) e a defender o consumidor (art. $5^{\circ}$, XXXII; art. 170, V) etc." 55

53 "O princípio do desenvolvimento sustentável, além de impregnado de caráter eminentemente constitucional, encontra suporte legitimador em compromissos internacionais assumidos pelo Estado brasileiro e representa fator de obtenção do justo equilíbrio entre as exigências da economia e as da ecologia, subordinada, no entanto, a invocação desse postulado, quando ocorrente situação de conflito entre valores constitucionais relevantes, a uma condição inafastável, cuja observância não comprometa nem esvazie o conteúdo essencial de um dos mais significativos direitos fundamentais: o direito à preservação do meio ambiente, que traduz bem de uso comum da generalidade das pessoas, a ser resguardado em favor das presentes e futuras gerações" (ADI 3.540-MC, Rel. Min. Celso de Mello, j. em 1ํ-9-2005, Plenário, DJ de 3-2-2006).

54 "É certo que a ordem econômica na Constituição de 1988 define opção por um sistema no qual joga um papel primordial a livre-iniciativa. Essa circunstância não legitima, no entanto, a assertiva de que o Estado só intervirá na economia em situações excepcionais. Mais do que simples instrumento de governo, a nossa Constituição enuncia diretrizes, programas e fins a serem realizados pelo Estado e pela sociedade. Postula um plano de ação global normativo para o Estado e para a sociedade, informado pelos preceitos veiculados pelos seus arts. $1^{\circ}, 3^{\circ}$ e 170. A livre-iniciativa é expressão de liberdade titulada não apenas pela empresa, mas também pelo trabalho. Por isso a Constituição, ao contemplá-la, cogita também da 'iniciativa do Estado'; não a privilegia, portanto, como bem pertinente apenas à empresa. Se de um lado a Constituição assegura a livre-iniciativa, de outro determina ao Estado a adoção de todas as providências tendentes a garantir o efetivo exercício do direito à educação, à cultura e ao desporto (arts. 23, V, 205, 208, 215 e 217, § $3^{\circ}$, da Constituição). Na composição entre esses princípios e regras há de ser preservado o interesse da coletividade, interesse público primário. O direito ao acesso à cultura, ao esporte e ao lazer são meios de complementar a formação dos estudantes" (ADI 1.950, Rel. Min. Eros Grau, j. em 3-11-2005, Plenário, DJ de 2-6-2006). No mesmo sentido: ADI 3.512, j. em 15-2-2006, Plenário, DJ de 23-62006.

55 DJNr. 174 do dia 12/08/2019 Plenário RepublicaçõesADC/42-AçÃODECLARATÓRIADE CONSTITUCIONALIDADE Procedência: DISTRITO FEDERAL Relator: MIN. LUIZ FUX 
Destarte nossa Constituição Federal, ao fixar em 1988 os princípios fundamentais antes indicados (conteúdo dos Arts. $1^{\circ}$ e $3^{\circ}$ ) ,teria adotado em certa medida parte das ideias contidas no documento intitulado Nosso Futuro Comum e especificamente recepcionado o "conceito" de desenvolvimento sustentável conforme indicado no Art. 225 de nossa Lei Maior" conforme salienta Fiorillo (FIORILLO,2021) corroborado por orientação do Supremo Tribunal Federal ${ }^{56}$.

Com efeito.

Elaborado, como já aduzido anteriormente, pela Comissão Mundial sobre o Meio Ambiente e o Desenvolvimento e dentro de um contexto em que "o meio ambiente não existe como uma esfera desvinculada das ações, ambições e necessidades humanas (grifos nossos)", o desenvolvimento sustentável, na definição estabelecida em referido documento," é aquele que atende às necessidades do presente sem comprometer a possibilidade de as gerações futuras atenderem a suas próprias necessidades".

Repetindo pois lição de Fiorillo57:"o desenvolvimento sustentável contem, conforme está escrito em referido documento que elabora sua definição," dois conceitos-chave:

1) o conceito de "necessidades", sobretudo as necessidades essenciais dos pobres no mundo, que devem receber a máxima prioridade e

2) a noção das limitações que o estágio da tecnologia e da organização social impõe ao meio ambiente, impedindo-o de atender às necessidades presentes e futuras".

Por via de consequência ficou explicitamente indicado no Relatório Brundtland que "satisfazer as necessidades e aspirações humanas é o principal objetivo do desenvolvimento" vez que " nos países em desenvolvimento, as necessidades básicas de grande número de pessoas - alimento, roupa, habitação, emprego - não estão sendo atendidas. Além dessas necessidades básicas, as pessoas também aspiram legitimamente uma melhor qualidade de vida". Destarte, "para que haja um desenvolvimento sustentável, é preciso que todos tenham atendidos as suas necessidades básicas e Ihes sejam proporcionadas oportunidade de concretizar suas aspirações a uma vida melhor"

56 "A QUESTÃO DO DESENVOLVIMENTO NACIONAL (CF, ART. 3, II) E A NECESSIDADE DE PRESERVAÇÃO DA INTEGRIDADE DO MEIO AMBIENTE (CF, ART. 225): O PRINCÍPIO DO DESENVOLVIMENTO SUSTENTÁVEL COMO FATOR DE OBTENÇÃO DO JUSTO EQUILÍBRIO ENTRE AS EXIGÊNCIAS DA ECONOMIA E AS DA ECOLOGIA. - O princípio do desenvolvimento sustentável, além de impregnado de caráter eminentemente constitucional, encontra suporte legitimador em compromissos internacionais assumidos pelo Estado brasileiro e representa fator de obtenção do justo equilíbrio entre as exigências da economia e as da ecologia, subordinada, no entanto, a invocação desse postulado, quando ocorrente situação de conflito entre valores constitucionais relevantes, a uma condição inafastável, cuja observância não comprometa nem esvazie o conteúdo essencial de um dos mais significativos direitos fundamentais: o direito à preservação do meio ambiente, que traduz bem de uso comum da generalidade das pessoas, a ser resguardado em favor das presentes e futuras gerações". ADI 3540 MC / DF - DISTRITO FEDERAL MEDIDA CAUTELAR NAAÇÃO DIRETA DE INCONSTITUCIONALIDADE Relator: Min. CELSO DE MELLO Julgamento: 01/09/2005 Órgão Julgador: Tribunal Pleno Publicação DJ 03-022006 PP-00014 EMENT VOL-02219-03 PP-00528.

57 FIORILLO, Celso Antonio Pacheco. in Curso de Direito Ambiental Brasileiro. $21^{\text {a }}$ edição São Paulo: Editora Saraiva, 2021. 
Claro está que ao estabelecer como princípios fundamentais constitucionais o objetivo de "erradicar a pobreza e a marginalização e reduzir as desigualdades sociais e regionais"(Art. $3^{\circ}$, III) adotando como fundamento "a dignidade da pessoa humana"(Art. $\left.1^{\circ}, \mathrm{III}\right)^{58}$ nossa Constituição Federal teria, ao que tudo indica, usado claramente pelo menos um dos "conceito chave" do significado do conceito de desenvolvimento sustentável inclusive com reflexo direto na positivação constitucional dos princípios gerais da atividade econômica que, praticamente repetindo o conteúdo do art. $1^{\circ}$ da Carta Maior estabelece que a ordem econômica é fundada na valorização do trabalho humano e na livre iniciativa e tem por fim assegurar a todos existência digna, conforme os ditames da justiça social, observados alguns princípios, como o princípio da defesa do meio ambiente Em síntese, e para usar a feliz expressão de Kruja ${ }^{59}$.

sustainable development is an instant increase of welfare for all inhabitants, not compromising the welfare of others in the nearest and further future.So, in order to satisfy the concept of sustainable development, it should be studied the best possible use of allavailable economic resources for the production of maximum possible output of goods and services that are needed forthe community now and in the future and the just distribution of this output.

Daí o Supremo Tribunal Federal, adotando interpretação realizada pela doutrinadesde o inicio do século XXI conforme podemos constatar de obras como as de Fiorillo60, estabelecer, que "o desenvolvimento sustentável passou, assim, a ser o objetivo a ser alcançado por todos os países, com previsão expressa no Princípio n. 4 da Declaração sobre o Meio Ambiente e Desenvolvimento (ECO-92, Rio de Janeiro, 1992), que firma: "Para alcançar o desenvolvimento sustentável, a proteção ambiental deve constituir parte integrante do processo de desenvolvimento, e não pode ser considerada isoladamente deste" destacando que "no Brasil, a constitucionalização de uma ordem ambiental voltada ao dever estatal de proteção do meio ambiente, bem como seu deslocamento para o rol de direitos fundamentais, consagrou modelo de Estado que considera a proteção ambiental e o fenômeno do desenvolvimento "um objetivo comum, pressupondo a convergência de objetivos das políticas de desenvolvimento econômico, social e cultural e de proteção ambiental ${ }_{1}{ }^{61}$.

58 "O direito à integridade do meio ambiente - típico direito de terceira geração - constitui prerrogativa jurídica de titularidade coletiva, refletindo, dentro do processo de afirmação dos direitos humanos, a expressão significativa de um poder atribuído, não ao indivíduo identificado em sua singularidade, mas, num sentido verdadeiramente mais abrangente, à própria coletividade social. Enquanto os direitos de primeira geração (direitos civis e políticos) - que compreendem as liberdades clássicas, negativas ou formais - realçam o princípio da liberdade e os direitos de segunda geração (direitos econômicos, sociais e culturais) - que se identificam com as liberdades positivas, reais ou concretas - acentuam o princípio da igualdade, os direitos de terceira geração, que materializam poderes de titularidade coletiva atribuídos genericamente a todas as formações sociais, consagram o princípio da solidariedade e constituem um momento importante no processo de desenvolvimento, expansão e reconhecimento dos direitos humanos, caracterizados, enquanto valores fundamentais indisponíveis, pela nota de uma essencial inexauribilidade". [MS 22.164, rel. min. Celso de Mello, j. 30-10-1995, P, DJ de17-11-1995.]

59 KRUJA, Alba. Sustainable Economic Development, a Necessity of the 21st Century Mediterranean. Rome (Italy), Journal of Social Sciences MCSER Publishing, Vol. 4, nº 10 October 2013.

60 FIORILLO, Celso Antonio Pacheco. in Curso de Direito Ambiental Brasileiro. São Paulo: Editora Saraiva, 2000.

61 ADI 4269 / DF - DISTRITO FEDERAL Relator: Min. EDSON FACHIN Julgamento: 18/10/2017 Órgão Julgador: Tribunal Pleno Publicação ACÓRDÃO ELETRÔNICO DJe-019 DIVULG 31-01-2019 PUBLIC 01-02-2019 
As empresas no Brasil, em face dos argumentos antes apontados, está estruturalmente subordinada ao princípio do desenvolvimento sustentável e, portanto ajustadas por força de nossa Carta Magna a perseguir um ou mais objetivos de benefício comum e atuando de forma responsável, sustentável e transparente com as pessoas, comunidades, territórios e meio ambiente, ativos e atividades culturais e sociais, entidades e associações e demais stakeholders no âmbito da legislação em vigor.

\section{CONSIDERAÇÕES FINAIS}

Saudada pela mídia italiana, como lembram Frignani e Virano 62 "com anúncios entusiásticos como uma ferramenta que quer reescrever a economia" e tendo como principal objetivo permitir a difusão no ordenamento jurídico italiano de empresas que, no exercício da sua atividade económica, têm também como objetivo a melhoria do ambiente natural e social em que operam, reduzindo ou eliminando as externalidades negativos ou, antes, pela utilização de práticas, processos produtivos e bens capazes de produzir externalidades positivas, e que visam destinar parte de seus recursos gerenciais e econômicos à busca do crescimento do bem-estar das pessoas e comunidades, à conservação e recuperação de ativos do património artístico e arqueológico presente no local onde se insere ou no território nacional, à divulgação e apoio a atividades culturais e sociais, bem como a organismos e associações com fins que visam a comunidade e o bem-estar social, as denominadas empresas de benefícios instituídas na legislação italiana ainda que possam representar ,segundo os autores da norma ${ }^{63}$ a primeira disposição da União Europeia para regulamentar este tipo de sociedades e tornar a Itália o país líder na divulgação de sociedades de benefício comum, não revelam, salvo melhor juízo, qualquer contribuição significativa para o direito empresarial ambiental brasileiro.

Assim, embora guardando em certa medida compatibilidade com os principais vetores ambientais constitucionais que estruturam todas as empresas no Brasil, conforme demonstrado no presente trabalho, e mesmo representando um interessante avanço em proveito do desenvolvimento sustentável em face do tradicional balizamento normativo que sempre condicionou uma empresa tradicional geralmente definida para maximizar tão somente o lucro para os acionistas, as denominadas empresas de benefícios revelam objetivamente tímida

62 FRIGNANI, A.; VIRANO, P. Le società benefit: luci e ombre. Giappichelli Editore, 2018.

63 "La presente proposta, pertanto, potrebbe rappresentare il primo provvedimento nell'ambito dell'Unione europea a disciplinare tale tipologia di società e fare dell'Italia il Paese capofila nella diffusione di società con scopo di beneficio comune". Senato della Repubblica XVII LEGISLATURAN. 1882 DISEGNO DI LEGGE d'iniziativa dei senatori DEL BARBA, Mauro Maria MARINO, SANTINI, COCIANCICH, ASTORRE, COLLINA, CUOMO, DI GIORGI, FABBRI, FRAVEZZI, GUERRIERI PALEOTTI, LAI, LUCHERINI, MIRABELLI, PEZZOPANE, SANGALLI, SCALIA e SPOSETTI COMUNICATO ALLA PRESIDENZA IL 17 APRILE 2015 
contribuição normativa, constatada aliás também por Calagna ${ }^{64}$, visando enriquecer de forma efetiva e estrutural nosso bem elaborado balizamento normativo constitucional disciplinador das atividades econômicas no Brasil.

\section{REFERÊNCIAS DAS FONTES CITADAS}

BONFANTE, Pietro Lezioni di. Storia del commercio: Era moderna. Oceânica: A. Giuffrè, 1982.

BULGARELLI, Waldírio. A Teoria Jurídica da Empresa: análise jurídica da empresarialidade. São Paulo: Editora Revista dos Tribunais, 1985.

CABRILLO, Francisco. La economía del desarrollo en el siglo XXI - El desafío actual consiste en extender el progreso a aquellos países y a aquellas personas que todavía hoy viven en condiciones lamentables. Nueva Revista, 2009.

CALAGNA, Francesca. La nuova disciplina della "Società Benefit": profili normativi e incertezze applicative. Rivista di Diritto Societario. Vol. 3. 2016.

COASE, R.H. The problem os social cost. The Journal of Law and Economics. Vol. 3, Number ct., 1960.

COMPARATO, Fábio Konder. A reforma da empresa. RDM, n. 50, 1983.

COMPARATO, Fábio Konder. Estado, Empresa e Função Social. São Paulo: Revista dos Tribunais, vol. 732, 1996.

DODD, Jr. E. Merrick For Whom Are Corporate Managers Trustees? Harvard Law Review Vol. 45, n. 8, maio de 1932.

ENDERS, Armelle; FERREIRA, Marieta de Moraes; FRANCO, Renato. História em Curso Da antiguidade à Globalização. São Paulo: Editora do Brasil; Rio de Janeiro: Fundação Getulio Vargas, 2008.

FIORILLO, Celso Antonio Pacheco. in Curso de Direito Ambiental Brasileiro. 21 a edição São Paulo: Editora Saraiva, 2021.

FIORILLO, Celso Antonio Pacheco. in Curso de Direito Ambiental Brasileiro. São Paulo: Editora Saraiva, 2000.

FIORILLO, Celso Antonio Pacheco; FERREIRA, Renata Marques. Direito Empresarial Ambiental Brasileiro e sua delimitação constitucional. Rio de Janeiro: Lumen Juris, 2020.

FIORILLO, Celso Antonio Pacheco; FERREIRA, Renata Marques. Liberdade Econômica (lei 13.874/19) em face do direito ambiental constitucional brasileiro: o enquadramento jurídico das atividades econômicas vinculadas ao desenvolvimento sustentável. Rio de Janeiro: Lumen Juris, 2020.

FIORILLO, Celso Antonio Pacheco; FERREIRA, Renata Marques. Atividades Econômicas Sustentáveis e Função Social da Empresa em Face do Direito Ambiental Constitucional Brasileiro. RJLB - Revista Jurídica Luso-Brasileira, vol. 2, p. 1143-1171, 2019.

FREEMAN, R. Edward. Stockholders and Stakeholders: A New Perspective on Corporate Governance. California Management Review. (pre-1986); Spring 1983.

FRIGNANI, A.; VIRANO, P. Le società benefit: luci e ombre. Giappichelli Editore, 2018.

GHIDINI, Mario. Lineamenti del Diritto Del'Impresa. Milão: Giuffrè; 1978.

64 A advertência de Calagna, a saber "l'interesse al perseguimento di finalità di beneficio comune è, in quanto tale, imputabile non solo a categorie di individui differenziate e qualificate (ad es., i lavoratori) ma anche, in misura significativa, alla collettività in generale. In questo senso, il riferimento della legge di stabilità alla tutela dell'ambiente e alla promozione di attività culturali e sociali nonché le definizioni delle aree e degli standard di valutazione contenute negli allegati alla stessa legge confermano la rilevanza di interessi diffusi e non è chiaro se tali interessi siano forniti di una tutela specifica avverso gli atti gestori compiuti senza procedere al bilanciamento prescrito" é reveladora da fragilidade da norma no âmbito dos direitos difusos... 
Novos Estudos Jurídicos

GRAU, Eros Roberto. Comentários ao artigo 170. in Comentários à Constituição do Brasil. São Paulo: Saraiva/ Almedina, 2013.

GUTIÉRREZ, Carlos Gómez. El desarrollo sostenible: conceptos básicos, alcance y criterios para su evaluación. https://en.unesco.org/, 2017.

HOUAISS, Antonio; VILLAR, Mauro de Salles. Dicionário Houaiss da Língua Portuguesa. Rio de Janeiro: Objetiva, 2009.

HESSE, Konrad. Elementos de Direito Constitucional da República Federal da Alemanha. Porto Alegre: Sergio Antonio Fabris Editor, 1998.

KRUJA, Alba. Sustainable Economic Development, a Necessity of the 21st Century Mediterranean. Rome (Italy), Journal of Social Sciences MCSER Publishing, Vol. 4, nº 10 October 2013.

LEITE, Antonio Dias. A Economia Brasileira: de onde viemos e onde estamos. $2^{\mathrm{a}}$ edição, Rio de Janeiro: Elsevier, 2011.

NERY, Rosa. Vínculo obrigacional: relação jurídica de razão (Técnica e ciência de proporção), tese de livre-docência, Pontifícia Universidade Católica de São Paulo, 2004.

ONU. Nosso Futuro Comum. $2^{a}$ edição, Rio de Janeiro: Editora Fundação Getúlio Vargas, 1991.

REQUIÃO, Rubens. Curso de Direito Comercial. $8^{a}$ edição, São Paulo: Saraiva, 1977.

RODRIGUES JUNIOR, Otavio Luiz. A influência do BGB e da doutrina alemã no direito civil brasileiro do século XX. São Paulo: Revista dos Tribunais, 2013.

SANDRONI, Paulo. Novíssimo Dicionário de Economia. São Paulo: Best Seller, 1999.

WIEACKER, Franz. História do Direito Privado Moderno Lisboa: Fundação Calouste Gulbenkian, 1993.

Recebido em: 20/07/2020

Aprovado em: $17 / 11 / 2020$ 